\title{
An improved zero-voltage zero-current transition boost converter employing L-C-S resonant network
}

\author{
Anandh N. ${ }^{1}$, Akhilesh Sharma ${ }^{2}$, Julius Fusic S. ${ }^{3}$, Ramesh H. ${ }^{4}$ \\ ${ }^{1}$ Department of Electrical and Electronics Engineering, Manipal Institute of Technology, Manipal Academy of Higher, \\ India \\ ${ }^{2}$ Department of Electrical Engineering, North Eastern Regional Institute of Science and Technology, India \\ ${ }^{3,4}$ Department of Mechatronics Engineering, Thiagarajar College of Engineering, India
}

\begin{tabular}{|c|c|}
\hline Article Info & ABSTRACT \\
\hline Article history: & An improved zero-voltage zero-current transition boost converter \\
\hline Received Dec 6, 2019 & $\begin{array}{l}\text { (IZVZCTBC) is introduced. This converter is basically a fourth-order DC- } \\
\text { DC converter wherein a L-C-S (Inductor-Capacitor-Switch) resonant circuit }\end{array}$ \\
\hline Revised Mar 18, 2020 & is embedded for soft-switching. L-C-S tank network is the modified version \\
\hline Accepted May 19, 2020 & of conventional ZVZCT switch cell. The main feature of L-C-S tank circuit \\
\hline Keywords: & $\begin{array}{l}\text { converter in terms of eliminating the high current stress, decreasing the } \\
\text { switching losses and increasing the efficiency of converter. This converter }\end{array}$ \\
\hline Digital controller & exhibits both zero-voltage turn on and zero-current turn off switching \\
\hline High current stress & $\begin{array}{l}\text { characteristics based on the gating signals applied to switches. The principle } \\
\text { of operation and time domain expressions of IZVZCT boost converter with }\end{array}$ \\
\hline Improved zvzct boost converter & L-C-S cell are presented. For the closed loop operation, digital controller is \\
\hline $\mathrm{L}-\mathrm{C}-\mathrm{S}$ resonant network & designed and the performance of the controller has been validated through \\
\hline Soft-switching & $\begin{array}{l}\text { simulation for different line and load variations. The mathematical and } \\
\text { theoretical analysis is verified accurately by a } 12-24 \mathrm{~V}, 30 \mathrm{~W} \text { converter } \\
\text { through PSIM simulation software and the results ensures that overall } \\
\text { efficiency of the converter has improved to } 97 \% \text { along with elimination of } \\
\text { current stress. }\end{array}$ \\
\hline
\end{tabular}

This is an open access article under the CC BY-SA license.

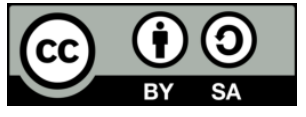

\section{Corresponding Author:}

Anandh N.,

Department of Electrical and Electronics Engineering,

Manipal Institute of Technology,

Manipal Academy of Higher Education, Manipal - 576104, Karnataka, India.

Email: anandh.n@manipal.edu

\section{INTRODUCTION}

Modern era deals with new power electronic technologies to satisfy the needs and requirements of industries. High frequency DC-DC converters are predominantly utilized to serve industrial needs. Converters with high frequency has more advantages compared to low frequency operations, increased frequency provides large power density, quick response, reduction in physical size, cost and weight of reactive elements. Besides these merits, it also offers demerits such as high switching losses and stress, poor efficiency and electromagnetic interference noise. These difficulties can be rectified with soft-switching technologies and they are of mainly four types, i) Zero-Voltage Switching, ii) Zero-Current Switching, iii) Zero-Voltage Transition, iv) Zero-Current Transition. Among the four, first two switching techniques mainly deals with increasing efficiency and reducing the losses but it does not account on switch stress, but the second two transition techniques provides high efficiency, reduced losses and switch stress. Apart from the 
mentioned techniques, there is another technique that combines both ZVT and ZCT methods, called as ZVZCT technique which offers advantages of both the techniques [1-10].

An active snubber cell based ZVZCT boost converter was introduced wherein the snubber cell plays a role in providing ZVT and ZCT for main switch of the converter [1]. A ZVT/ZCT/PWM snubber cell based converter was reported in which the cell offers ZVT turn on and ZCT turn off for main switch by employing single quasi resonating network [2]. A snubber cell based ZVT/ZCT DC-DC converter was introduced, where additional current/voltage stress are neglected on main switch and current stress on additional switch is reduced by coupling inductance [3]. A new snubber cell based ZVT-ZCT converter was presented which increases the converter efficiency, power density and reduces the EMI noise [4]. In ZCZVT quasi-resonant buck converter, where an active snubber network renders ZVT turn on and ZCT turn off collectively for the switches present in the converter without any other voltage and current stress [5]. A zero-voltage/zero-current transition converter using snubber was developed in [6], where the operation was verified on a high power converter wherein a high efficiency of about $98 \%$ was obtained at $100 \mathrm{kHz}$ switching frequency.

A three-level half bridge ZVZCS PWM DC/DC converter was introduced wherein ZVS and ZCS are achieved through parasitic inductance of transformer, snubber capacitors and tapped inductor type smoothing filter, this converter does not possess ancillary resonant circuit to obtain soft-switching [7]. A new ZVZCT boost converter employing a coupling inductor was developed, in which the switches and diodes undergo soft-switching and improves the efficiency with reduced circulating current due to the coupling effect [8]. An optimized ZVZCT boost converter was achieved by using a coupling inductor, the main advantage of this topology is that the steady-state condition of main switch can be optimized by fixing the coupling inductance ratio for each desired load [9]. A soft-switching boost converter with coupled inductor and an extra switch was analyzed, here the coupled-inductor delivers the energy to the load, which minimizes the auxiliary switch current stress and also helps in improving the efficiency of converter [10]. Voltagemultiplier cell and coupled-inductors integrated high static gain DC/DC soft-switching converter was presented, in which the multiplier cell along with coupled-inductors play a vital role in reducing switch voltage, conduction losses and it also improves the efficiency [11]. A magnetically coupled auxiliary network based ZCZVT inverter is proposed in [12], which overcomes the reactive energy problem and improves the efficiency.

A ZCZVT commutation cell based DC/DC PWM converter was addressed [13] which offers the benefits of both soft-transition methods. A commutation cell based true ZCZVT DC/DC PWM converter was explained in which commutation cell offers ZCS and ZVS for main switch during turn off and turn on simultaneously [14]. A high efficient ZVZCT converter for battery cell equalization was addressed wherein by employing the volt-sec balance principle of inductor and transformer coupling, the battery cells are equalized and by including ancillary resonant network at the main switching devices, ZVS and ZCS are achieved with elimination of losses [15]. A synchronous rectification based ZCZVT forward converter was introduced, wherein the converter is operated with synchronous rectification to minimize conduction losses of the rectifier at load side and to improve the overall efficiency to 89\% [16]. A soft-switching ZCZVT boost power converter was analyzed and a classical controller was designed in order to neglect source voltage variation and to attain load voltage regulation [17].

A zero-voltage transition fifth-order boost converter undergoes soft-switching for the switching devices and also voltage-mode digital controller for the converter have been discussed in [18]. A LCLC resonant network based bidirectional soft-switching DC/DC converter was analyzed, this converter is an improved version of traditional bidirectional converter by replacing the isolation transformer with LCLC resonance circuit to achieve high efficiency with high boost ratios [19]. An enhanced zero-voltage transition boosting converter was introduced in which a LCS resonant cell is employed to attain the soft-switching of the devices, to improve efficiency and to eliminate the peak current stress of the converter [20].

A soft-switching interleaved boost converter for fuel cell application was proposed, in which two similar boost converters are connected in parallel and controlled by interleaved switching signals. This converter is widely used for high efficiency fuel cell power systems in which it improves the electrical performance, efficiency and it also reduces the switching loss, size and weight of the converter [21]. A new zero voltage transition bidirectional DC-DC converter was introduced for battery back-up systems in hybrid electric vehicles, which reduces the turn-on switching losses, switch current stress and improves the efficiency [22]. A review of various soft-switching techniques was carried out based on the topology, resonant circuit location, performance characteristics and principle of operation. In addition, converters area of application, merits and demerits are also addressed [23]. 


\section{ANALYSIS AND PRINCIPLE OF OPERATION OF IZVZCTBC}

The proposed Improved Zero-Voltage Zero-Current Transition Boost Converter is presented in Figure 1. Normally, an auxiliary network comprising of additional switch, diode, inductor and capacitor are sufficient to realize the resonance phenomenon in the converter which offers higher efficiency and reduced switching losses, but there is a huge current stress and conduction losses across the main switch. In order to avoid this, a slight modification in the auxiliary network is done by adding one more series inductor with main switch and the proposed L-C-S resonant network comprised of auxiliary switch $\left(\mathrm{S}_{\mathrm{Aux}}\right)$, auxiliary diode $\left(D_{\text {Aux }}\right)$, resonating inductor $\left(L_{r}\right)$, resonating capacitor $\left(C_{r}\right)$ and a main series inductor $\left(L_{\text {Main }}\right)$. The resonance is taking place among the auxiliary soft-switching capacitor $\left(\mathrm{C}_{\mathrm{r}}\right)$ and energy transferring inductor $\left(\mathrm{L}_{\mathrm{r}}\right)$. Also, for a short interval of period, the resonating capacitor exchanges energy with the parallel combination of $L_{r}$ and $\mathrm{L}_{\text {Main. }}$. Proper selection of $\mathrm{C}_{\mathrm{r}}, \mathrm{L}_{\mathrm{r}}$ and $\mathrm{L}_{\text {Main }}$ will be vital for achieving the IZVZCT operation.

Following are the assumptions to be made in order to make the analysis simpler. At input side, the existence of huge inductor $\left(\mathrm{L}_{1}\right)$ in series with voltage source has been substituted with the magnitude of $\mathrm{I}_{\mathrm{g}}$ (constant source current). At load side, the existence of huge capacitor $\left(\mathrm{C}_{\mathrm{o}}\right)$ in parallel with load has been substituted with the magnitude of $\mathrm{V}_{0}$ (constant source voltage). It is assumed that all the switching devices and energy storing components are ideal. The status of individual switching devices in each mode of IZVZCT operation is given in the Table 1 . Waveforms of voltages and currents across/through the different switches during one cycle of operation are shown in Figure 2, Figures $3 \& 4$ depicts the structural variations in ZVT/ZCT operations.

Table 1. Status of individual switching devices in each mode of IZVZCT operation

\begin{tabular}{|c|c|c|c|c|c|}
\hline $\begin{array}{c}\text { Mode of } \\
\text { operation }\end{array}$ & $\begin{array}{c}\text { Time } \\
\text { duration }\end{array}$ & $\mathrm{S}_{\text {Main }}$ & $\mathrm{S}_{\text {Aux }}$ & $\mathrm{D}_{\text {Main }}$ & $\mathrm{D}_{\text {Aux }}$ \\
\hline Mode 1 & $\mathrm{t}_{0}<\mathrm{t}<\mathrm{t}_{1}$ & $X$ & $\sqrt{ }$ & $\sqrt{ }$ & $\sqrt{ }$ \\
\hline Mode 2 & $\mathrm{t}_{1}<\mathrm{t}<\mathrm{t}_{2}$ & $X$ & $\sqrt{ }$ & $\mathrm{X}$ & $\sqrt{ }$ \\
\hline Mode 3 & $\mathrm{t}_{2}<\mathrm{t}<\mathrm{t}_{3}$ & $\begin{array}{c}\mathrm{X} \\
\text { (Body diode - ON) }\end{array}$ & $\sqrt{ }$ & $\mathrm{X}$ & $\sqrt{ }$ \\
\hline Mode 4 & $\mathrm{t}_{3}<\mathrm{t}<\mathrm{t}_{4}$ & $\begin{array}{c}\mathrm{X} \\
\text { (Body diode - ON) }\end{array}$ & $\begin{array}{c}\mathrm{X} \\
\text { (Body diode - ON) }\end{array}$ & $X$ & $\sqrt{ }$ \\
\hline Mode 5 & $\mathrm{t}_{4}<\mathrm{t}<\mathrm{t}_{5}$ & $\begin{array}{c}\mathrm{X} \\
\text { (Body diode - ON) }\end{array}$ & $\mathrm{X}$ & $X$ & $\sqrt{ }$ \\
\hline Mode 6 & $\mathrm{t}_{5}<\mathrm{t}<\mathrm{t}_{6}$ & $\frac{\mathrm{X}}{(\text { Body diode }-\mathrm{ON})}$ & $X$ & $\sqrt{ }$ & $X$ \\
\hline Mode 7 & $\mathrm{t}_{6}<\mathrm{t}<\mathrm{t}_{7}$ & $\sqrt{ }$ & $\mathrm{X}$ & $\sqrt{ }$ & X \\
\hline Mode 8 & $\mathrm{t}_{7}<\mathrm{t}<\mathrm{t}_{8}$ & $\sqrt{ }$ & $\mathrm{X}$ & $\mathrm{X}$ & $X$ \\
\hline Mode 9 & $\mathrm{t}_{8}<\mathrm{t}<\mathrm{t}_{9}$ & $\sqrt{ }$ & $\sqrt{ }$ & $\mathrm{X}$ & X \\
\hline Mode 10 & $\mathrm{t}_{9}<\mathrm{t}<\mathrm{t}_{10}$ & $\sqrt{ }$ & $\sqrt{ }$ & $\mathrm{X}$ & $\sqrt{ }$ \\
\hline Mode 11 & $\mathrm{t}_{10}<\mathrm{t}<\mathrm{t}_{11}$ & $\begin{array}{c}\mathrm{X} \\
\text { (Body diode - ON) }\end{array}$ & $\begin{array}{c}\mathrm{X} \\
\text { (Body diode - ON) }\end{array}$ & $\mathrm{X}$ & $\sqrt{ }$ \\
\hline Mode 12 & $\mathrm{t}_{11}<\mathrm{t}<\mathrm{t}_{12}$ & $\mathrm{X}$ & $\mathrm{X}$ & $\mathrm{X}$ & $\sqrt{ }$ \\
\hline Mode 13 & $\mathrm{t}_{12}<\mathrm{t}<\mathrm{T}_{\mathrm{s}}$ & $\mathrm{X}$ & $\mathrm{X}$ & $\sqrt{ }$ & $\mathrm{X}$ \\
\hline
\end{tabular}

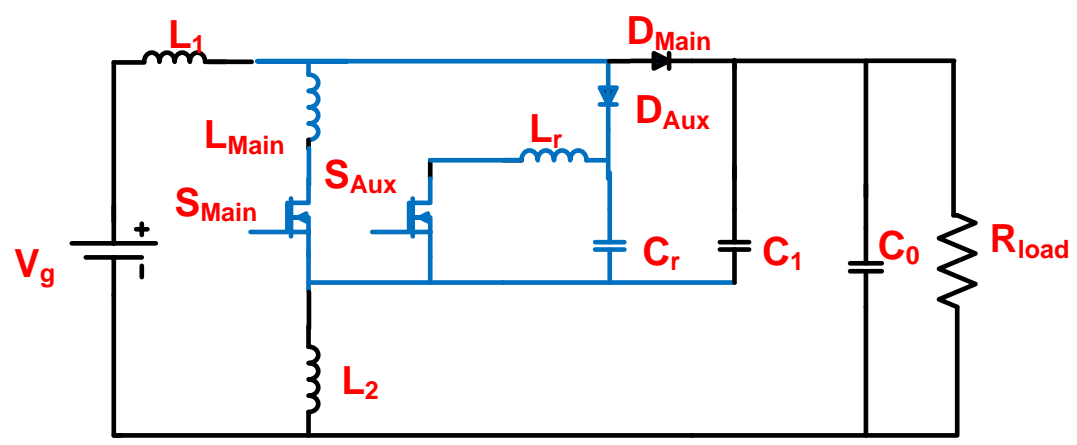

Figure 1. Proposed Improved ZVZCT Boost Converter 


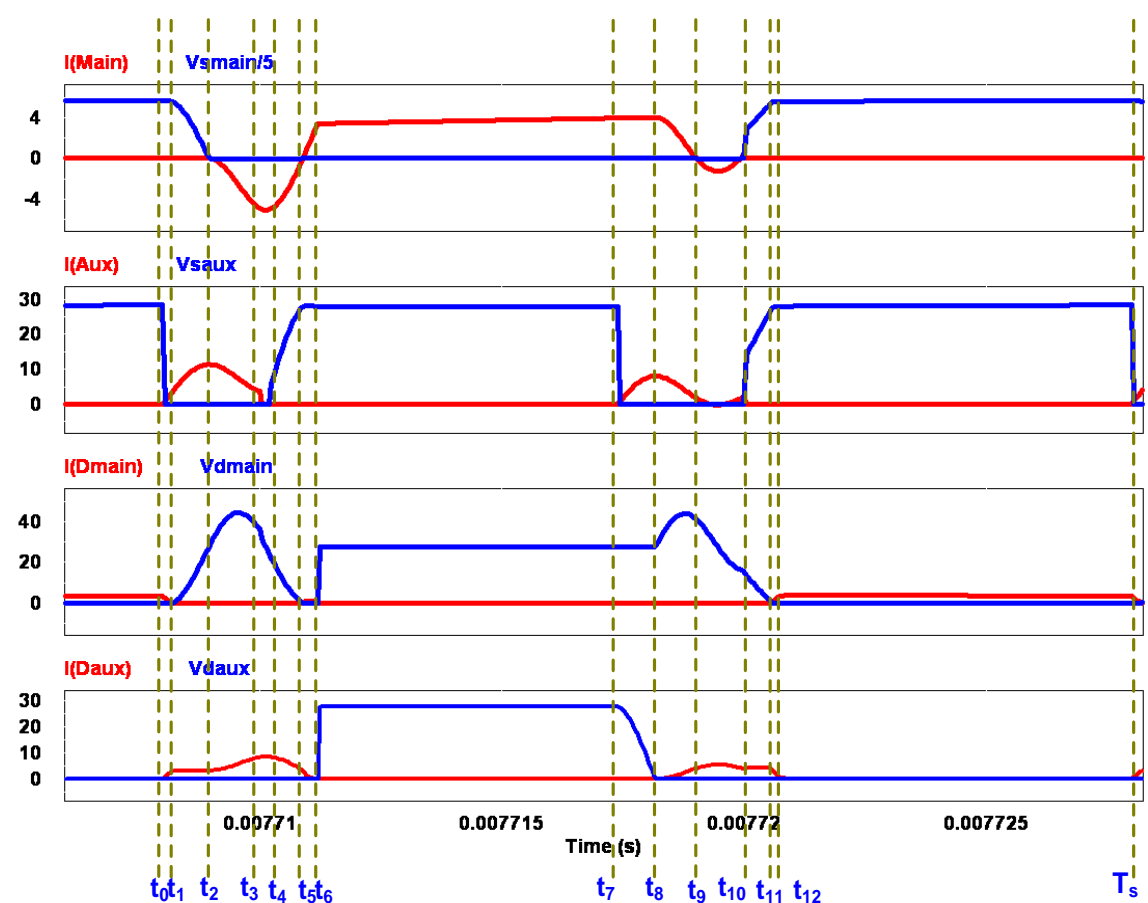

Figure 2. Voltage/Current waveforms of various switching devices in IZVZCT operation
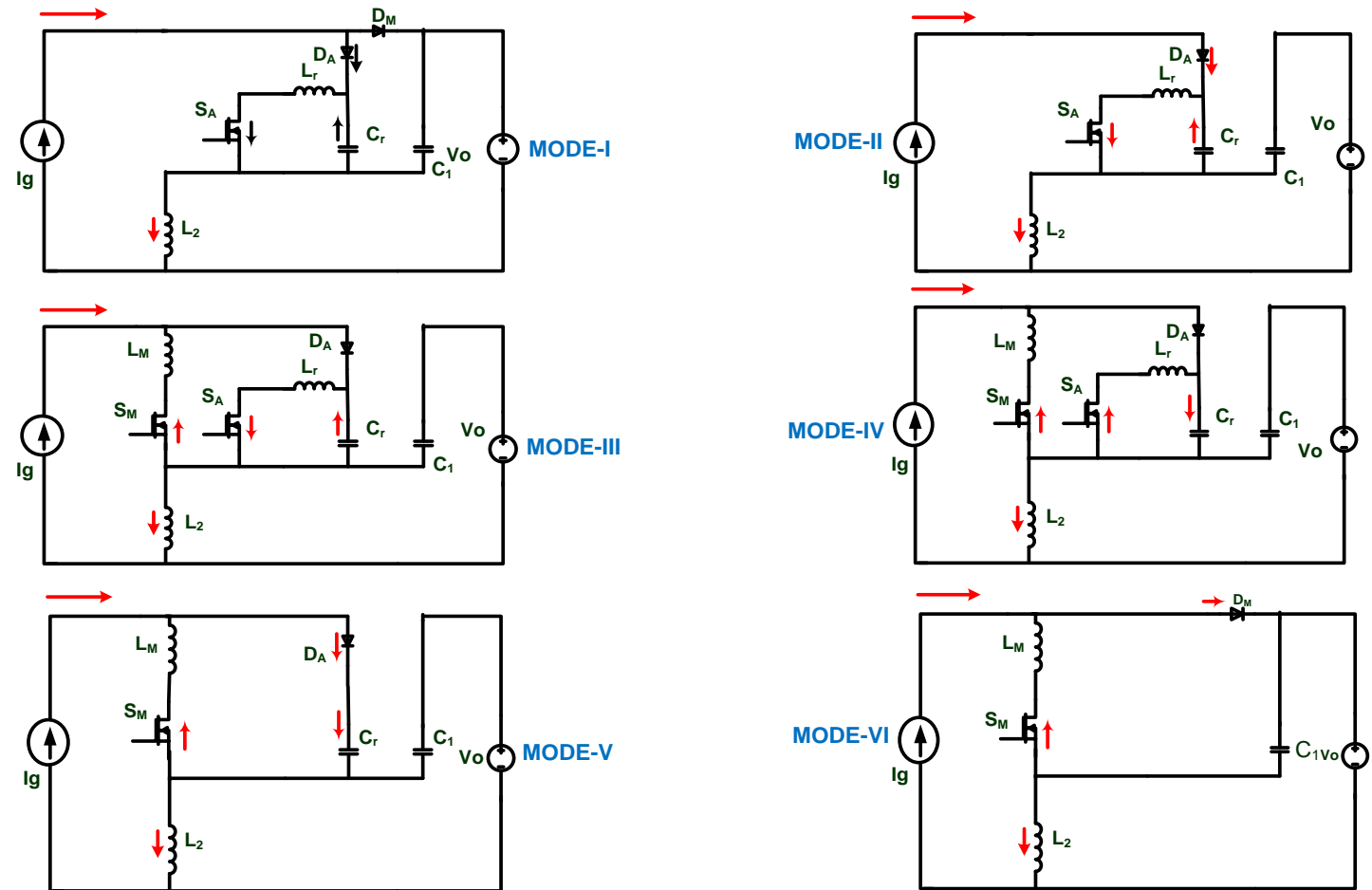

Figure 3. Structural variations in ZVT operation 

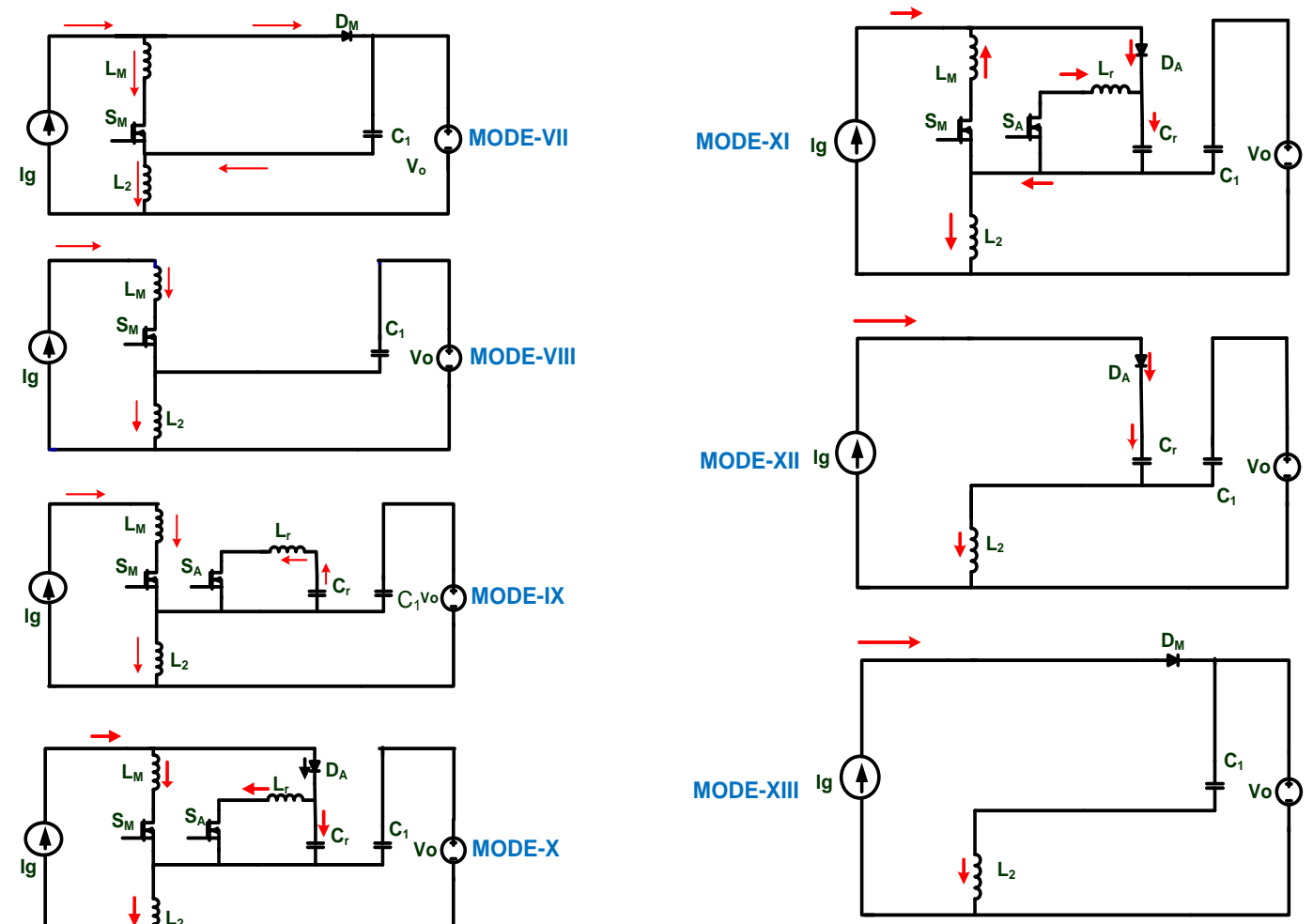

Figure 4. Structural variations in ZCT operation

\subsection{Operating modes in a switching cycle}

\section{Mode $I\left(t_{0}-t_{1}\right)$ :}

Prior to this mode, the circuit was in freewheeling mode with main diode alone conducting. Before triggering main switch, trigger the auxiliary switch in subsequent time which reduces the voltage across main switch to become zero, before it turns ON (with ZVS condition). The duration of this mode of operation is given by $t_{1}$.

Initial conditions:

$$
\begin{aligned}
& v_{C_{r}}(0)=V_{o}, i_{L_{r}}(0)=0, i_{D_{A}}(0)=0 \\
& t_{1}=\frac{1}{\omega_{r_{1}}} \operatorname{Sin}^{-1}\left(\frac{I_{g} Z_{r}}{2 V_{o}}\right)
\end{aligned}
$$

Mode II $\left(t_{1}-t_{2}\right)$ :

Initial conditions:

$$
\begin{aligned}
& v_{C_{r}}(0)=V_{o} \operatorname{Cos}\left[\omega_{r_{1}}\left(t_{1}-t_{0}\right)\right], \quad v_{C_{r}}{ }^{1}(0)=-V_{o} \operatorname{Sin}\left[\omega_{r_{1}}\left(t_{1}-t_{0}\right)\right], \quad i_{L_{r}}(0)=\frac{V_{o}}{z_{r}} \operatorname{Sin}\left[\omega_{r_{1}}\left(t_{1}-t_{o}\right)\right], \\
& i_{D_{A}}(0)=I_{g}{ }^{i_{D_{A}}}(0)=I_{g}
\end{aligned}
$$

The time domain equation of this mode is,

$$
t_{2}=t_{1}+\left(\frac{1}{\omega_{r_{1}}}\right) \operatorname{Tan}^{-1}\left[\operatorname{Cot}\left\{\omega_{r}\left(t_{1}-t_{0}\right)\right\}\right]
$$

By the completion of this mode, the voltage across main switch goes to zero and favorable conditions for ZVS turn on of $\mathrm{S}_{\mathrm{M}}$ will prevail.

Mode III $\left(t_{2}-t_{3}\right)$ :

Initial conditions: 


$$
v_{C_{r}}(0)=0, i_{D_{A}}(0)=I_{g}, i_{L_{r}}(0)=I_{g}-\frac{V_{o}}{z_{r}}\left[\operatorname{Sin}\left\{\omega_{r}\left(t_{2}-t_{1}\right)-\omega_{r_{1}}\left(t_{1}-t_{0}\right)\right\}\right]
$$
obtained is,

During this mode, resonating capacitor starts charging and main inductor current equation

$$
i_{L_{M}}\left(t^{1}\right)=I_{g}-\frac{2 V_{o}}{z_{r}}\left[\operatorname{Sin}\left\{\omega_{r}\left(t_{2}-t_{1}\right)-\omega_{r_{1}}\left(t_{1}-t_{0}\right)\right\}\right]
$$

Mode IV $\left(t_{3}-t_{4}\right)$ :

Resonating capacitor $\left(\mathrm{C}_{\mathrm{r}}\right)$ charges to its full value before this mode. During this mode, $I_{g}=i_{L_{M}}$, main inductor $\left(\mathrm{L}_{\mathrm{M}}\right)$ charges linearly through a steady source current $\left(\mathrm{I}_{\mathrm{g}}\right)$.

Mode $V\left(t_{4}-t_{5}\right)$ :

In this mode, main switch is switched OFF in hard-switching condition.

Mode VI $\left(t_{5}-t_{6}\right)$ :

This duration is equivalent to free-wheeling interval of traditional boost converter.

Mode VII $\left(t_{6}-t_{7}\right)$ :

The time domain equation of this mode is,

$$
t_{7}=I_{g} \frac{\left(L_{2}+L_{M}\right)}{V_{0}}
$$

Mode VIII $\left(t_{7}-t_{8}\right)$ :

In this interval, a steady-state current equal to $I_{g}$ flows through the main switch and this interval exists till the firing of auxiliary switch.

$$
t_{8}=\left(\mathrm{D}-\mathrm{D}_{\text {Saux }}\right) T_{s}
$$

Mode IX $\left(t_{8}-t_{9}\right)$ :

This mode begins with the switching $\mathrm{ON}$ of auxiliary switch and the time domain equation is given by $t_{9}$, Initial conditions:

$$
\begin{aligned}
& i_{L_{M}}(0)=I_{g}, v_{C_{r}}(0)=V_{0}, i_{L_{r}}(0)=0 \\
& t_{9}=t_{8}+\frac{\pi}{2} \sqrt{L_{r} C_{r}}
\end{aligned}
$$

Mode $X\left(t_{9}-t_{10}\right)$ :

Initial conditions:

$i_{L_{M}}(0)=I_{g}, v_{C_{r}}(0)=0, i_{L_{r}}(0)=\frac{V_{0}}{Z_{r}}, v_{L_{2}}(0)=0$,

and the time domain equation of this mode is,

$$
t_{10}=t_{9}+\left[\frac{1}{\omega_{o}}\right] \operatorname{Cos}^{-1}\left[\left\{\frac{-I_{g} \omega_{o} L_{M} \sqrt{1+L_{r} / L_{M}}}{V_{o} \operatorname{Sin} \omega_{r}\left(t_{9}-t_{8}\right)}\right\}+1\right]
$$

Mode XI $\left(t_{10}-t_{11}\right)$ :

The time domain equation of this mode is,

$$
t_{11}=t_{9}+\left[\frac{1}{\omega_{o}}\right]\left[\pi+\operatorname{Cos}^{-1}\left\{-1+\left(\frac{\omega_{o} \sqrt{1+L_{r} / L_{M}}}{\omega_{r} \sin \left(\omega_{r}\left(t_{9}-t_{8}\right)\right)}\right)\right\}\right]
$$

Mode XII $\left(t_{11}-t_{12}\right)$ :

During this mode, the main diode voltage will be decreasing as the resonating capacitor is charging.

$$
t_{12}=t_{11}+\left[C_{r}\left\{V_{o}-V_{o} \frac{\operatorname{Sin}\left[\omega_{r}\left\{\left(t_{9}-t_{8}\right)\right\}\left\{\operatorname{Sin}\left[\omega_{o}\left(t_{11}-t_{10}\right)\right]\right\}\right]}{I g\left(\sqrt{\left.1+L_{r} / L_{M}\right)}\right.}\right\}\right]
$$


Mode XIII $\left(t_{12}-t_{13}\right)$ :

In this interval, main diode current reaches a steady-state value and this interval prevails till the main switch is turned $\mathrm{ON}$ at, $t_{13}=T_{s}$.

\section{GATING SEQUENCE AND DESIGN OF POWER STAGE COMPONENTS}

Gating sequence requirement in case of improved ZVZCT scheme is presented in Figure 5. According to the discussion, the modified scheme offers certain advantages for execution of IZVZCT operation. In this the switching pattern is synchronized such that it helps in real time implementation. In case of normal ZVZCT operation, the first pulse of $\mathrm{S}_{\mathrm{A}}$, in which the ascending side of main switch gating signal must be matched with descending side of the auxiliary switch gating pulse, this pulse is called ZVS pulse for auxiliary switch and the second pulse of $S_{A}$, in which the descending side of $S_{M}$ and $S_{A}$ gate pulses should coincide (should be withdrawn simultaneously). This pulse is called ZCT pulse for the auxiliary switch.

In the modified version of ZVZCT operation, even after $S_{M}$ is switched $O N$, the gate pulse of $S_{A}$ is to be continued for some extended time, to achieve the soft-switching. This is called time delay 1 which starts between the starting of the gating pulse for main switch and the instant of withdrawing the gating pulse to auxiliary switch. Similarly, even after the $S_{M}$ is switched OFF, the gate pulse of $S_{A}$ is to be continued for some extended time, in order to achieve the soft-switching and this is called time delay 2 between the instant of withdrawal of the gate pulse for $S_{M}$ and the instant of withdrawing the gate pulse to $S_{A}$.

On observing the gate pulse requirement needed for the auxiliary switch for both ZVT and ZCT operations, it has been thought to apply the combination of both pulses as depicted in Figure 5 . Here, the auxiliary switch will be switched twice as compared to the main switch in a given switching cycle. In other words, the switching frequency of $S_{A}$ will be twice that of $S_{M}$. The design parameters of the converter are given below in Table 2 .

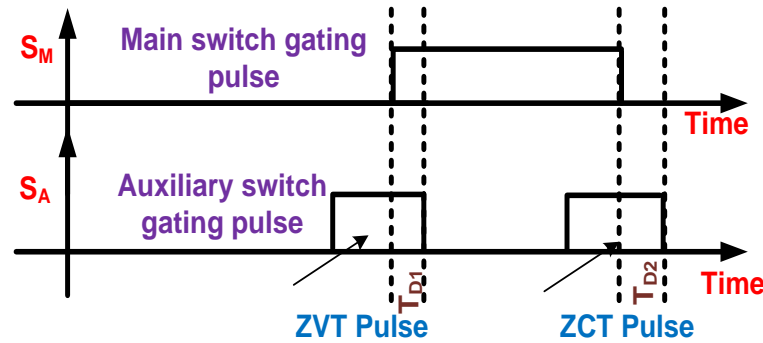

Figure 5. Gating sequence requirement in IZVZCT scheme
Table 2. Design values of power stage

\begin{tabular}{lc}
\multicolumn{2}{c}{ components } \\
\hline \multicolumn{1}{c}{ Parameters } & Design values \\
\hline Power output $\left(\mathrm{P}_{\mathrm{o}}\right)$ & $30 \mathrm{~W}$ \\
Output voltage $\left(\mathrm{V}_{\mathrm{o}}\right)$ & $24 \mathrm{~V}$ \\
Switching frequency $\left(\mathrm{f}_{\mathrm{s}}\right)$ & $100 \mathrm{kHz}$ \\
Input inductor 1 $\left(\mathrm{L}_{1}\right)$ & $120 \mu \mathrm{H}$ \\
Input inductor 2 $\left(\mathrm{L}_{2}\right)$ & $25 \mu \mathrm{H}$ \\
Main inductor $\left(\mathrm{L}_{\mathrm{M}}\right)$ & $0.7 \mu \mathrm{H}$ \\
Load capacitor $1\left(\mathrm{C}_{0}\right)$ & $200 \mu \mathrm{F}$ \\
Load capacitor 2 $\left(\mathrm{C}_{1}\right)$ & $52 \mu \mathrm{F}$ \\
Resonance inductor $\left(\mathrm{L}_{\mathrm{r}}\right)$ & $0.5 \mu \mathrm{H}$ \\
Resonance capacitor $\left(\mathrm{C}_{\mathrm{r}}\right)$ & $200 \mathrm{nF}$ \\
\hline
\end{tabular}

\section{1. Necessary and sufficient conditions for IZVZCT operation}

In order to achieve IZVZCT operation, the necessary and sufficient conditions will be same as that of ZVZCT modes of operation. In other words, the duration of the auxiliary switch pulse during ZVT and ZCT cannot be the same. If they are same, for the positive variation of the loads, the violation of the ZCT soft-switching happens although ZVT may be still satisfying. Here, the input and output operating conditions are set such that ZCT is satisfied over wide range. If the converter satisfies the ZCT then ZVT is automatically ensured but vice-versa is not true. In such case, certain operating conditions may satisfy the ZVT while violating the ZCT conditions. The above information is due to the design of the converter. Basically, it is done for achieving ZCT and by employing suitable gating sequence ZVT and IZVZCT operations can also be achieved. On observing the necessary and sufficient conditions for both the operations, the duration of ZVT pulse requirement is lesser than the duration of ZCT pulse. In other words, for the same ZVT and ZCT pulses of the auxiliary switch, the margin in achieving ZVT is more as compared to ZCT for positive load changes.

\section{DESIGN OF VOLTAGE-MODE CONTROLLER}

As, this higher-order converter is experiencing different topological variations over one switching cycle. Due to this, it is a challenging task to achieve the transfer function of the system by state-space 
approach. Hence, by employing system identification tool and by $\mathrm{P} \& \mathrm{O}$ method, the system transfer function is obtained for IZVZCT operation with suitable interval (greater than 85\%). Implementation of analog controllers are already existing and now-a-days digital controllers are more focused because of their added merits such as lesser sensitivity to noise, greater sensitivity to changes in parameters and less vulnerability to aging and environmental issues.

Among different control techniques, the voltage-mode scheme is better and highly effective. Further, it provides good dynamic response and also there is no stability problems. Thus, a digital voltagemode controller is employed for the modified ZVZCT converter. The transfer function of the plant $\mathrm{G}_{\mathrm{p}}(\mathrm{z})$ for IZVZCT operation has been obtained with the help of system identification tool and this is given in equation 10. Output Error (OE) method has been adapted and for a best fit of $88.9 \%$, the transfer function obtained is

$$
\frac{\hat{v}_{o}(z)}{\hat{d}(z)}=\frac{-0.003134 z^{3}+0.1271 z^{2}-0.1556 z+0.005982}{z^{4}-3.838 z^{3}+5.519 z^{2}-3.525 z+0.8434}
$$

The voltage-mode controller is designed considering the above transfer function of open loop system is,

$$
G_{c}(z)=0.10635 * \frac{(z-0.875)(z-0.961)}{(z-1)(z-0.912)}
$$

Utilizing the transfer functions of plant $\left(\mathrm{G}_{\mathrm{p}}(\mathrm{z})\right)$, compensator $\left(\mathrm{G}_{\mathrm{c}}(\mathrm{z})\right)$, and loop gain is expressed as,

$$
\mathrm{T}_{\mathrm{L}}(\mathrm{z})=\mathrm{G}_{\mathrm{p}}(\mathrm{z}) \mathrm{G}_{\mathrm{c}}(\mathrm{z})
$$

Figure 6 depicts the closed loop block diagram of the converter. The GM, PM and BW values for the designed controller are achieved from the bode plots of the open loop transfer function of converter and also with controller implementation are shown in Figures 7 and 8.

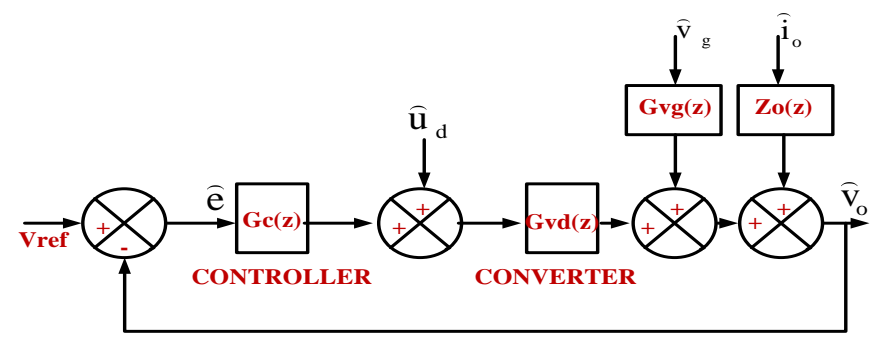

Figure 6. Block diagram of closed loop system

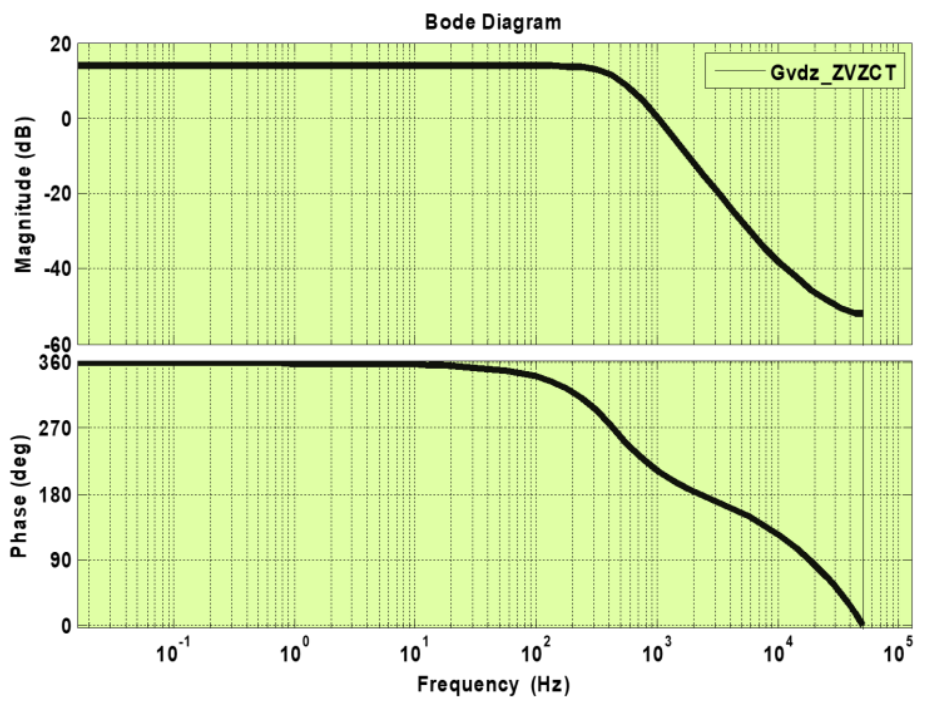

Figure 7. Frequency response characteristics of IZVZCTBC 
Figure 8 infers that, the $\mathrm{GM}$ is $10.5 \mathrm{~dB}, \mathrm{PM}$ is $33.5^{\circ}$ and the gain crossover frequency is $416 \mathrm{~Hz}$, which are all satisfying stability criteria for the designed controller. The frequency response plots of the Converter $\left(\mathrm{G}_{\mathrm{p}}(\mathrm{z})\right)$, Controller $\left(\mathrm{G}_{\mathrm{c}}(\mathrm{z})\right)$ and Loop gain $\left(\mathrm{T}_{\mathrm{L}}(\mathrm{z})\right)$ are shown in Figure 9.
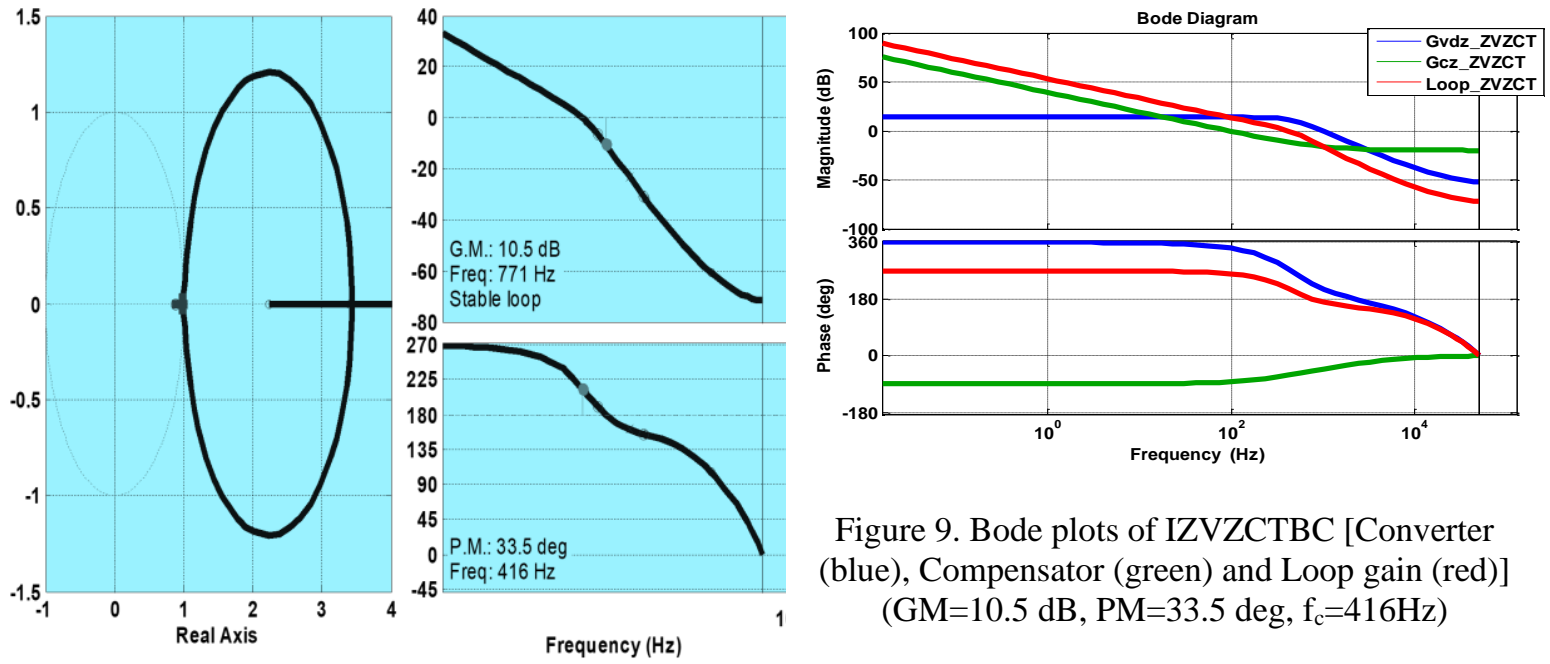

Figure 9. Bode plots of IZVZCTBC [Converter (blue), Compensator (green) and Loop gain (red)]

$\left(\mathrm{GM}=10.5 \mathrm{~dB}, \mathrm{PM}=33.5 \mathrm{deg}, \mathrm{f}_{\mathrm{c}}=416 \mathrm{~Hz}\right)$

Figure 8. PZ map and frequency response plot of IZVZCTBC

\section{VALIDATION OF CONTROLLER PERFORMANCE FOR IZVZCT OPERATION}

The designed digital controller has been verified for different input and output variations in simulation. Load variation of output resistance from $20 \Omega$ to $36 \Omega$ has been given and after 10 ms the voltage of the converter got regulated within $2 \mathrm{~ms}$ by the controller action. A sudden variation of $12 \mathrm{~V}$ to $15 \mathrm{~V}$ is applied to the source, which in turn made the transients to die down within $2 \mathrm{~ms}$ and also the performance of the controller was satisfactory and the matching results are depicted in Figure 10.

Ramp disturbance of $12 \mathrm{~V}$ to $15 \mathrm{~V}$ from $20 \mathrm{~ms}$ to $60 \mathrm{~ms}$ has been given as the input, in which it made the transients to die down within $2 \mathrm{~ms}$ and also the performance of controller is satisfactory. The corresponding results are shown in Figure 11.

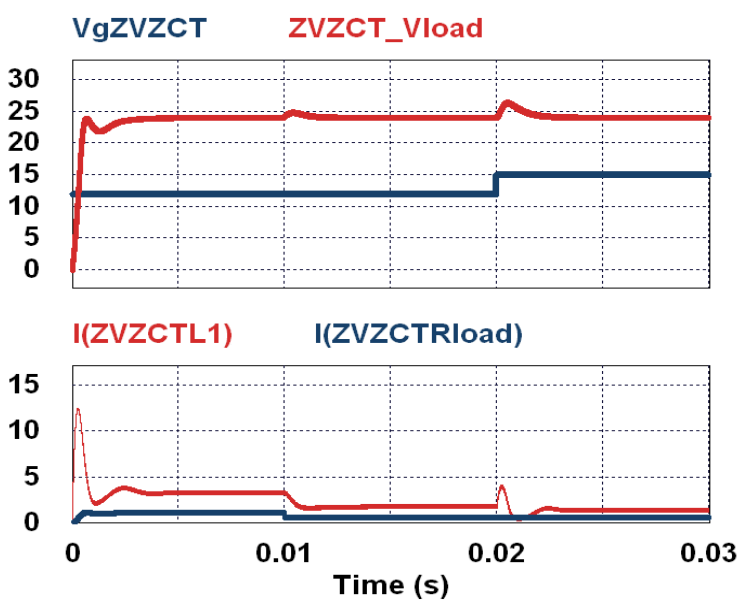

Figure 10. Dynamic response characteristics of IZVZCTBC, $\left(\mathrm{R}=20-36 \Omega\right.$ at $\mathrm{t}=10 \mathrm{~ms} ; \mathrm{V}_{\mathrm{g}}=12$ $15 \mathrm{~V}$ at $\mathrm{t}=20 \mathrm{~ms}$ )

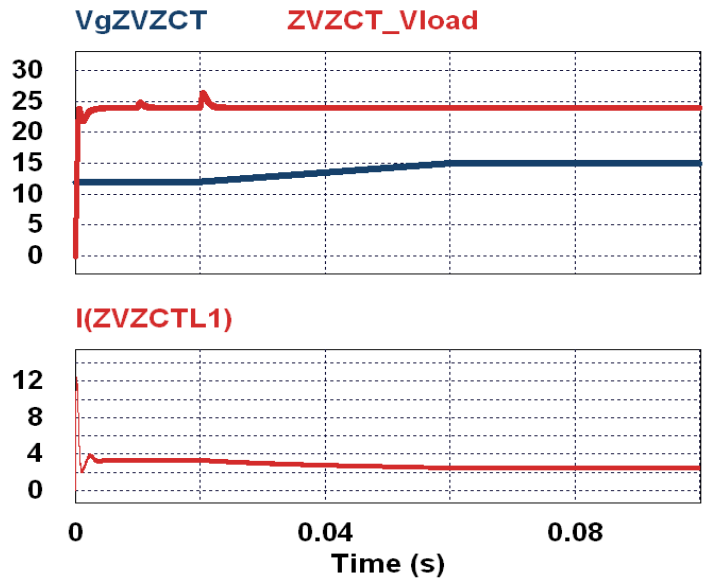

Figure 11. Dynamic response characteristics of IZVZCTBC, $\left(\mathrm{V}_{\mathrm{g}}=12-15 \mathrm{~V}\right.$ from $\left.20-60 \mathrm{~ms}\right)$ 


\section{RESULTS AND DISCUSSION}

As explained already, the peak in the main switch current during turn ON transition is present in the case of conventional ZVZCT networks and the relatively large negative peak in main switch current will be eliminated by incorporating the improved soft-switching cell under consideration into the converter. Figure 12. depicts the elimination of main switch current stress of IZVZCTBC.

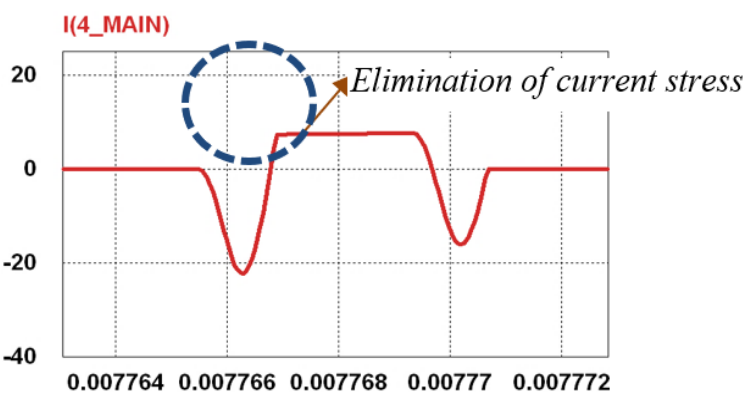

Figure 12. Elimination of main switch current stress

Figures 13, 14, 15 and 16 depicts the voltage/current waveforms of main and auxiliary switch, main and auxiliary diode. From these Figure s, it can be concluded that along with main and auxiliary switches the L-C-S tank network is also capable of providing soft-transition conditions for main and auxiliary diodes, whereas in conventional ZVZCT networks it can be noticed that it is providing soft-switching conditions primarily for $\mathrm{S}_{\mathrm{M}}$ and is not addressing the hard-switching problem of other switching devices.
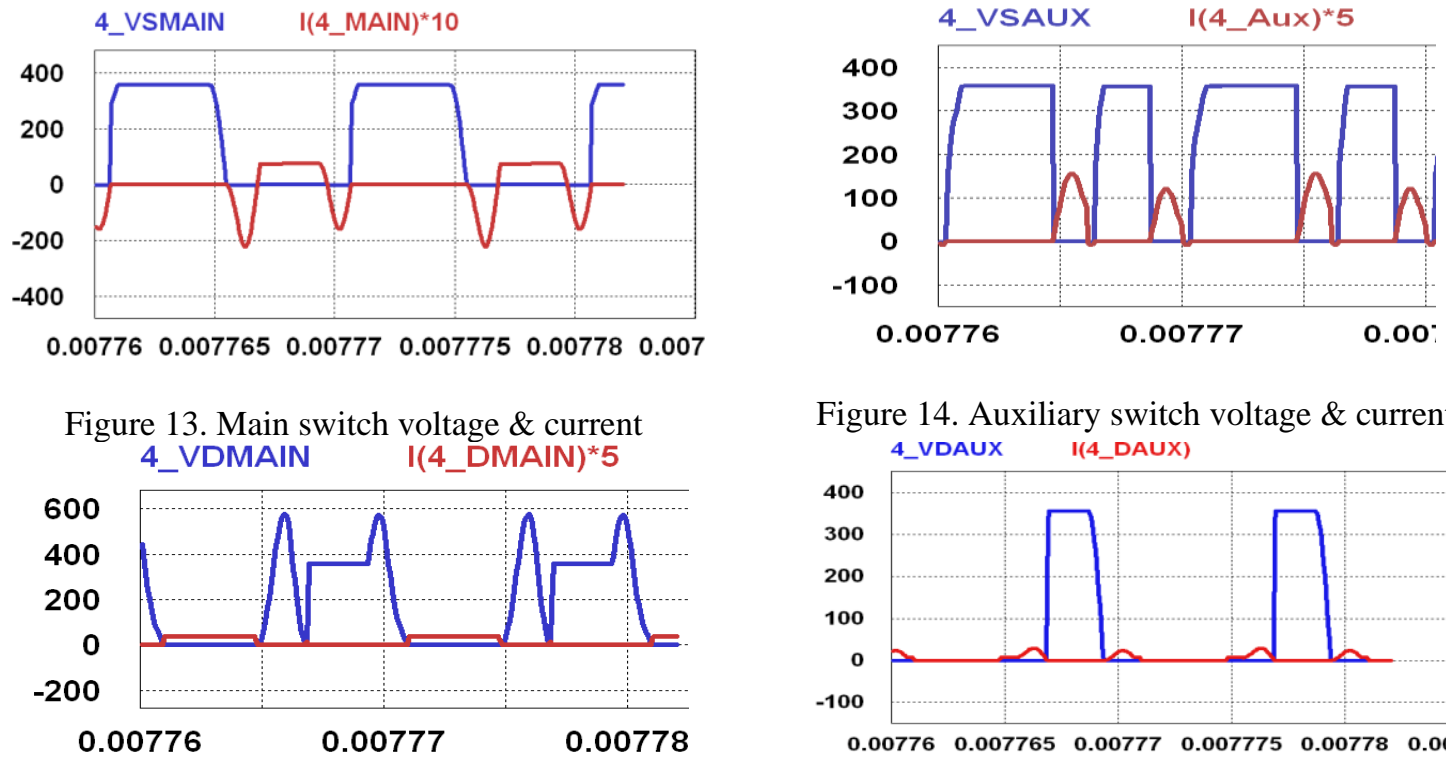

Figure 14. Auxiliary switch voltage \& current

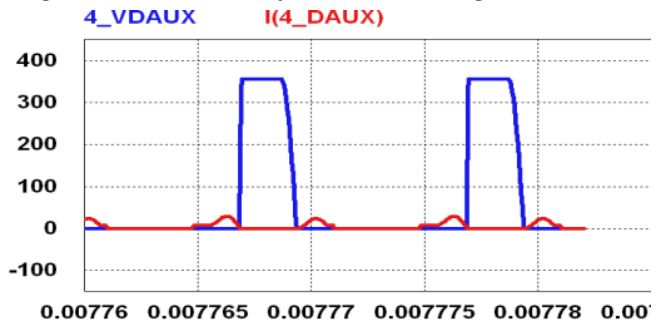

Figure 15. Main diode voltage \& current

Figure 16. Auxiliary diode voltage \& current

Theoretical losses and efficiency study for soft and hard-switched converters has been done and the results are depicted in Figure s 17 and 18. From the plots, it is clear that, at lighter loads, the efficiency of hard-switched converter is poor and increases for increasing loads. The efficiency will be maximum around nominal operating point, whereas in case of soft-switched converter, its light load efficiency is also better and is almost constant throughout the vast variation in load. The efficiency of hard-switched converter is about $89 \%$ at rated load and it is about $97 \%$ in case of soft-switched converter. The theoretical efficiencies of both hard and soft-switched converters have been plotted for the same rated load and examined that the softswitched converter is resulted in improved efficiency of about 5 to $8 \%$. 


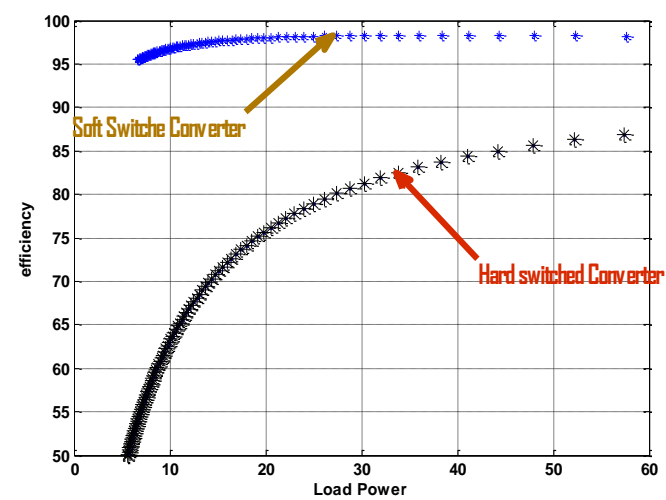

Figure 17. Comparison of Efficiency

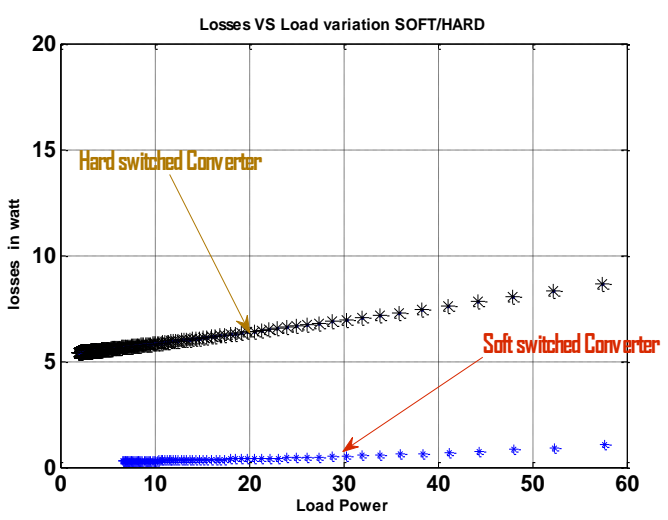

Figure 18. Comparison of Losses

\section{CONCLUSION}

An Improved Zero-Voltage Zero-Current Transition Boost Converter is introduced and its operational modes are described with time domain equations. The IZVZCTBC is the circuit modification of the traditional ZVZCT boost converter with extra auxiliary network elements and the converter topology is achieving ZVT, ZCT and IZVZCT for switching devices $\left(\mathrm{S}_{\mathrm{M}}, \mathrm{S}_{\mathrm{A}}, \mathrm{D}_{\mathrm{M}}, \mathrm{D}_{\mathrm{A}}\right)$, by applying proper sequence of gating signals for main and auxiliary switches. The choice of proper resonance network components is very significant in obtaining soft-transition operation for the switches. The ZVT/ZCT conditions are dependent on duty ratio of gate pulses, soft-switching capacitance/inductor and load. The structural advantage of the L-C-S tank network under consideration with the boost converter together is examined for the chances of achieving ZVT, ZCT and IZVZCT by properly adjusting the gate sequence to the auxiliary switch. The above investigation has been done without changing the various elemental values and with the employment of the proper gate sequence for the switches is able to achieve the ZVT, ZCT and IZVZCT.

The system identification technique was described and converter transfer function was obtained for IZVZCT operation and its frequency response analysis is presented. The voltage-mode digital controller for the converter has been designed using MATLAB [25] and it is validated in PSIM [24] simulation platform. The controller designed is regulating the load voltage for variations in load and input supply. The GM, PM and BW of the controller are satisfying the stability criteria and the IZVZCT operation of the two switches have been achieved in the simulation. This converter is suitable for point of load applications with power levels in the $\mathrm{kW}$ range.

\section{REFERENCES}

[1] A. Faruk Bakan, Haci Bodur, Ismail Aksoy, "A Novel ZVT-ZCT PWM DC-DC Converter," 2005 European Conference on Power Electronics and Applications, pp. 1-8, 2005.

[2] Hacı Bodur and A. Faruk Bakan, "A new ZVT-ZCT-PWM DC-DC Converter," IEEE Transactions on Power Electronics, vol. 19, no. 3, pp. 676-684, May 2004.

[3] Burak Akın, "An Improved ZVT-ZCT PWM DC-DC Boost Converter with Increased Efficiency," IEEE Transactions on Power Electronics, vol. 29, no. 4, pp. 1919-1926, April 2014.

[4] Ismail Aksoy, Haci Bodur and A. Faruk Bakan, "A new ZVT-ZCT-PWM DC-DC Converter," IEEE Transactions on Power Electronics, vol. 25, no. 8, pp. 2093-2105, August 2010.

[5] S. Urgun, "Zero-voltage transition-zero-current transition pulse-width modulation DC-DC buck converter with zero-voltage switching-zero-current switching auxiliary circuit," IET Power Electronics, vol. 5, no. 5, pp. 627-634, May 2012.

[6] Yukinori Tsuruta, Martin Pavlovsky and Atsuo Kawamura, "Conditions Limiting the Formation of the ZVZCT Switching in SAZZ Converter," IEEE Industry Applications Annual Meeting, Sep 2007.

[7] Enhui Chu, Xutong Hou, Huaguang Zhang, Mengyang Wu, Xiuchong Liu, "Novel Zero-voltage and Zero-current Switching (ZVZCS) PWM three-level DC/DC converter using output coupled inductor," IEEE Transactions on Power Electronics, vol. 29, no. 3, pp. 1082-1093, March 2014.

[8] Xi Zhang, Wei Qian, and Zhe Li, "Design and Analysis of a Novel ZVZCT Boost Converter with Coupling Effect," IEEE Transactions on Power Electronics, vol. 32, no. 12, pp. 8992-9000, Dec 2017.

[9] Zhe Li, Wei Qian and Xi Zhang, "An Optimized Zero-Voltage Zero-Current Transition Boost Converter Realized by Coupled Inductor," IEEE Transactions on Power Electronics, vol. 34, no. 9, pp. 8882-8893, Sep 2019. 
[10] Wei Qian, Xi Zhang, Zhe Li, "Design and Operation Analysis of a Novel Coupled-Inductor Based Soft Switching Boost Converter with an Auxiliary Switch," IEEE 8th International Power Electronics and Motion Control Conference (IPEMC-ECCE Asia), 2016.

[11] Martin Breus Meier, S. Avelino da Silva jr., Alceu Andr'e Badin, Eduardo F' elix Ribeiro Romaneli, and Roger Gules, "Soft-Switching High Static Gain DC-DC Converter without Auxiliary Switches," IEEE Transactions on Industrial Electronics, vol. 65, no. 3, pp. 2335-2345, March 2018.

[12] M.I. Da S. Martins, C.m. De O. Stein, J.L. Russi, J.R. Pinheiro, H.L. Hey, "Zero-Current Zero-Voltage Transition Inverters with magnetically coupled auxiliary circuits: analysis and experimental results," IET Power Electronics, vol. 4, no. 9, pp. 968-978, Nov 2011.

[13] H.L. Hey, C.M. De O. Stein, "A new family of soft-switching DC-DC PWM converters using a true ZCZVT commutation cell," IECON '98. Proceedings of the 24th Annual Conference of the IEEE Industrial Electronics Society, vol. 2, pp. 1030-1035, 1998.

[14] Carlos Marcelo de Oliveira Stein and Hélio Leaes Hey, "A true ZCZVT Commutation Cell for PWM Converters," IEEE Transactions on Power Electronics, vol. 15, no. 1, pp. 185-193, Jan 2000.

[15] Tae-hoon Kim, Nam-ju Park, Rae-young Kim, Dong-seok Hyun, "A High Efficiency Zero Voltage-Zero Current Transition Converter for Battery Cell Equalization," Twenty-Seventh Annual IEEE Applied Power Electronics Conference and Exposition (APEC), pp. 2590-2595, 2012.

[16] Sung-Pei Yang, Jong-Lick Lin and Shin-Ju Chen, "A Novel ZCZVT Forward Converter with Synchronous Rectification," IEEE Transactions on Power Electronics, vol. 21, no. 4, pp. 912-922, July 2006.

[17] Jong-Lick Lin and Chun-Hsiao Hsia, "Dynamics and Control of ZCZVT Boost Converters," IEEE Transactions on Circuits and Systems, vol. 52, no. 9, pp. 1919-1927, Sep 2005.

[18] Anandh N., Jayalakshmi N.S., S. Julius Fusic, "Voltage-mode Digital Controller for a Fifth-Order Zero-Voltage Transition Boost Converter," IEEE International Conference on Sustainable Energy Technologies and Systems (ICSETS), pp. 174-179, 2019.

[19] Yijie Wang, Hongyu Song and Dianguo Xu, "Soft-Switching Bidirectional DC/DC Converter with an LCLC Resonant Circuit," IEEE Journal of Emerging and Selected Topics in Power Electronics, vol. 7, no. 2, pp. 851-864, June 2019.

[20] Anandh Nagarajan, Sekaran Julius Fusic, "Analysis and Design of LCS Resonant Cell Based Enhanced ZeroVoltage Transition DC-DC Boosting Converter," Serbian Journal of Electrical Engineering, vol. 16, no. 1, pp. 105121, Feb 2019.

[21] R. Seyezhai, Harinee, Nagarajan, "Simulation and Implementation of Soft-Switched Interleaved DC-DC Boost Converter for Fuel Cell Systems," Bulletin of Electrical Engineering and Informatics, vol. 1, no. 3, pp. 203-208, Sep 2012.

[22] Rajesh Thumma, Veera Venkata Subrahmanya Kumar Bhajana, Pramod Kumar Aylapogu, "Design and Simulation of a New ZVT Bi-directional DC-DC Converter for Electric Vehicles," Indonesian Journal of Electrical Engineering and Computer Science, vol. 7, no. 1, pp. 75-83, July 2017.

[23] Abdul-Hakeem Mohammed Dobi, Mohd Rodhi Sahid, Tole Sutikno, "Overview of Soft-Switching DC-DC Converters," International Journal of Power Electronics and Drive System, vol. 9, no. 4, pp. 2006-2018, Dec 2018.

[24] PSIM User Manual, Power sim, Inc., 2007.

[25] MATLAB User Manual, 2005.

\section{BIOGRAPHIES OF AUTHORS}

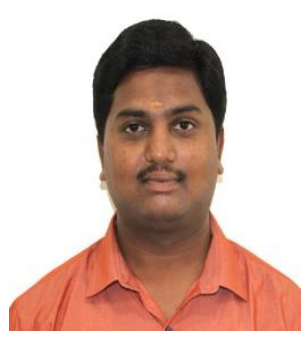

Mr. Anandh N. obtained his B.E. degree in Electrical and Electronics Engineering from Ranipet Engineering College, Anna University, Chennai in 2006 and M.Tech. degree in Power Electronics, Electrical Machines and Drives from Indian Institute of Technology Delhi (IIT-D), New Delhi in 2014. He also obtained his M.B.A. degree from Directorate of Distance Education, Pondicherry University, Puducherry. Currently, he is an Assistant Professor in the Department of Electrical and Electronics Engineering at Manipal Institute of Technology, a constituent unit of Manipal Academy of Higher Education (Deemed-to-be-University), Manipal, Karnataka, India. His research interests include Modeling and Analysis of Power Electronic Converter circuits, Soft-Switching Power Converters, Electrical Machines \& Drives, Power Quality analysis. He is a life member of Indian Society for Technical Education and Indian Science Congress Association.

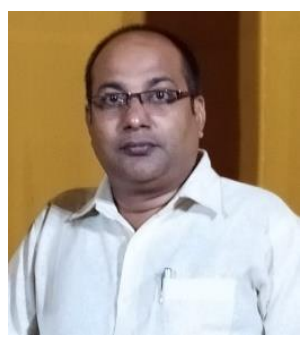

Mr. Akhilesh Sharma is working as Assistant Professor in North Eastern Regional Institute of Science \& Technology (A Deemed to be University under Ministry of Human Resource Development, Govt. of India), Nirjuli, Arunachal Pradesh, India. He did his Bachelor's degree in Electrical \& Electronics Engineering from Malnad College of Engineering, Hassan, Karnataka, India in 2002 and thereafter Master's degree in Power Electronics \& Drives from Madan Mohan Malaviya Engineering College, Gorakhpur in 2009. He has over a decade of teaching experience for under graduate students and almost five years at post graduate level. So far, he has attended and presented many papers in IEEE conferences and published 4 research papers. His area of interest includes Power Electronics and Electrical Drives. 

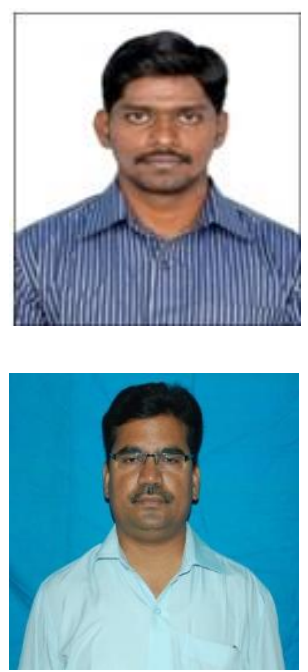

Mr. Julius Fusic S. obtained his B.E. degree in Electrical and Electronics Engineering from Anna University affiliated college in 2010 and M.E. degree in Power Electronics \& Drives from Anna University affiliated college in 2014. Currently, he is an Assistant Professor in the Department of Mechatronics Engineering at Thiagarajar College of Engineering (A Govt. Aided Autonomous Institution affiliated to Anna University), Madurai, Tamil Nadu, India. His research interests include Autonomous Systems, Electrical Machines, Power electronics, Mechatronics systems. He has published national and international research papers in technical and education research domain. He was awarded SAP Award for Excellence from IIT Bombay (Top 253 out of 4051 registered participants). He act as Mentor for IIT workshops like FDP 101x and 201x.

Mr. Ramesh H. obtained his B.E. degree in Electrical and Electronics Engineering from M.S University in 1997 and M.E. degree in Applied Electronics from Anna University, Chennai in 2012. He had worked as an Electrical Engineer both in India and Saudi Arabia for ten years. Currently, he is an Assistant Professor in the Department of Mechatronics Engineering at Thiagarajar College of Engineering, (A Govt. Aided Autonomous Institution affiliated to Anna University), Madurai, Tamil Nadu, India. His research interests include Electrical Drives, Motion control Systems and Industrial Drives. He had published national and international research papers in Motion Control applications. Presently, he is pursuing his research in Industrial Servo drives. 